Seloka: Jurnal Pendidikan Bahasa dan Sastra Indonesia
UNNES
https://journal.unnes.ac.id/sju/index.php/seloka

\title{
The Humanist Expressive Speech Acts of Journalists in the Covid-19 Outbreak
}

\author{
Areni Yulitawati Supriyono ${ }^{凶}$, Ida Zulaeha ,Tommi Yuniawan \\ Universitas Negeri Semarang, Indonesia
}

\begin{abstract}
Article Info
Abstract

History Articles

This research aims to analyze the humanist expressive speech acts of Received:

August 2020

Accepted:

Oktober 2020

Published:

December 2020

Keywords:

Covid-19, expressive, journalist, speech acts journalists in the covid-19 outbreak. The data collection technique was carried out by using the free non-participatory technique. The sources of data are the journalists' utterances on YouTube in the covid-19 Outbreak. The humanist expressive speech act forms used by journalists, is $58 \%$ used the direct speech act forms with imperative, interrogative, and declarative modes; and $42 \%$ forms of indirect speech acts were declarative-imperative and declarativeinterrogative modes. Results of this study shows that journalists use the forms of direct speech acts with declarative mode mostly. The form of indirect speech acts with the declarative-imperative mode are mostly used by the journalists. This research is important to be a journalist's guide so that the utterances spoken can be accepted by the society in the covid-19 outbreak.
\end{abstract}

Correspondence address:

J1. Welirang I/No 42, RT 05/RW 05, Karangrejo, Gajah Mungkur,

Kota Semarang-50235

p-ISSN 2301-6744

E-mail: areniyulitawatisupriyono@gmail.com 


\section{INTRODUCTION}

Language is a communication tool used by humans. The main function of language is as a communication tool or interaction tool (Chaer \& Agustina, 2004). Everyone has the good social competence; it is the ability of the one as a part of society to communicate and interact effectively with society.

The Indonesian government issued Presidential Decree No.11 on 2020 concerning the Determination of the 2019 Corona Virus Disease (Covid-19) Public Health Emergency. The government recommends keeping your distance, washing your hands and wearing a mask. Data on corona sufferers (https://covid19.who.int/table) in Indonesia until July $9^{\text {th }} 2020$, there were 70.736 positive records. This shows that the recommendation of the government has not been fully implemented by the community. It is contrast with the line that the government has made efforts to provide recommendations both verbally and in writing to the public.

During a pandemic, people tend to use social media more. It is not only for socialization, but there are other purposes such as promoting something or simply expressing themselves. Expressive utterance is very easy to find on social media nowadays, but not all expressive utterances can easily be accepted in society.

The press is an institution that is increasingly needed by the government, citizens and other institutions to exchange information. A journalist's main goal in a public health crisis is to help public health goals optimally and reduce risk while reducing public panic in uncertainty. Wilkins (2005) describes three functions of journalists. First, it provides accurate information about disease that is available for public, the medical and scientific community, and makes government decisions. Second, it is as the multi-directional information that delivery between the public-government or government-science, and the government and local-international institutions. Third, it is as supervising the government and related institutions to respond to certain events related to the crisis, both in the short and long term. The function of the journalist at first is a very big impact on the wider community, especially during the covid-19 outbreak.

Journalists have different characteristics of utterance in conveying information. In delivering information, the good communication process is influenced by the use of an appropriate utterance in this case. During an outbreak, the speech acts that people expect are humanist speech acts. It is hoped that humanist speech acts can make people to be calm in the facing of outbreak. The speech act means that in uttering an expression, the speaker does not merely say something by saying that expression. In pronouncing that expression, he also "acts" something (Purwo in Rustono, 1999). The form of speech acts is divided into direct and indirect speech acts (Wijana, 1996). Direct speech acts have a relation between the mode of speech and its conventional function. Indirect speech act is the irregularity of the mode with the function in one speech.

The importance of using humanist expressive speech acts by the journalists during the outbreak is very important. The good speech acts will facilitate the delivering of messages to the society properly. Through this research, humanist expressive speech acts of journalists will be found during the covid-19 outbreak.

Research on the topic of the covid-19 outbreak has been conducted by several researchers, including Agung (2020), Bavel (2020), Giatman (2020); Hardika (2020), Kurniawan (2020), Ristyawati (2020), Xiong (2020). Xiong concluded about psychological condition of the society during the covid-19 outbreak and the associated risk factors. A high prevalence of adverse psychiatric symptoms has been reported in most studies. The covid-19 outbreak represents an unprecedented threat to mental health in high, middle and low-income countries. Apart from flattening the curve of viral transmission, priority needs to be given to prevention of mental disorders (e.g. major depressive disorder, PTSD, and suicide). A combination of government policies that 
integrate virus risk mitigation with provisions to reduce harm to mental health is urgently needed.

Several researchers have conducted the research related to journalism. For example, research conducted by Mitchell (2014) examines the ethics of speaking and the representation of thoughts in literary journalism. The article written by Mitchel with the title The Ethics of Speech and Thought Representation in Literary Journalism discusses how ethics' speak of journalists. It is only ethical; it has not yet included the form of a journalist's speech. In the other hand, the researches on speech acts has been conducted by How \& Jan (2019), Ariyanti \& Zulaeha (2017), Ekawati (2017), Rini \& Wagiran (2018). The title of How \& Jan's research (2019) is "Speech Act of Concern on the Academic Performance of Malaysian Foster Children". How and Jan found that its attention was not only limited to one category of speech acts (expressive acts), but outside the categories of expressive acts representing acts, directive and commissive acts. The results showed that at a high level (i.e. refocusing), the more speech act categories were found because teachers and caregivers voiced concern in hopes of answering the foster children's academic needs and problems. The refocusing stage is the most prominent stage of attention in both teacher and caregiver responses and consists of three categories of speech acts, namely representative, directive and commissive. Meanwhile, the process and collaboration stages have two categories of speech acts.

The research of speech acts was also conducted by Ariyanti \& Zulaeha (2017) with the title of the article "Tindak Tutur Ekspresif Humanis dalam Interaksi Pembelajaran di SMA Negeri 1 Batang: Analisis Wacana Kelas". Ariyanti's research found that the imperative mode of direct speech tended to be more frequently spoken in the observation aspect. The most commonly used functions are the critique or suggest function. The use of humanist expressive speech acts in learning interactions between building school culture, building the image of the school in the public, and building the students' characters.
The research related to expressive utterance has also been conducted by Ekawati (2017) with the title of the article "Kesantunan Semu pada Tindak Tutur Ekspresif Marah dalam Bahasa Indonesia". Ekawati concluded that nonliteral indirect face-threatening acts (ironic madness) were face-threatening acts that were conveyed in an indirect sentence mode with non-explicit meaning. This angry speech act focuses on $\mathrm{O} 3$ and $\mathrm{O} 2$. Although in expressive speech acts of blaming and anger there are no maxims that support politeness, anger aimed at the third person is a realization of pseudo politeness. Pseudo politeness is in angry expressions conveyed not to the target or goal of angry actions but to other people (third person). The maxim of conformity, humility is maintained by not conveying anger in a prominent manner. Pseudo politeness also functions to maintain social relations between friends, family and community.

Rini \& Wagiran (2018) conducted research on humanist expressive speech acts with the article title "Humanist Expressive Utterance Function and Form in Teaching Learning Interaction at Vocational High School". The results of the study found that the form of speech used in the learning interaction was direct and indirect. The humanist expressive speech function is to criticize or suggest, express apologies, function to apologize, insinuate, and suggest.

From several studies conducted that are related to covid-19, there is no research that leads to speech actions during the covid-19 outbreak. The existing research, mostly directed at the health sector. It has no research that has examined the humanist expressive speech acts of journalists in the covid-19 outbreak in journalists' expressive utterance. Therefore, this research study focuses on the humanist expressive speech acts forms of journalists during the covid-19 outbreak.

\section{METHODS}

The approach in this research is divided into two, namely the theoretical approach and 
the methodological approach. The theoretical approach in this study uses a pragmatic approach. The methodological approach used in this research is a qualitative approach and a descriptive approach. Qualitative research is a research method used to examine the condition of natural objects. Qualitative research was chosen because the researcher's stability based on his research experience and qualitative methods can provide more complex details about phenomena that are difficult to reveal with quantitative methods.

The data in this research is in the form of speeches from several senior journalists in Indonesia, Najwa Shihab and Karni Ilyas during the covid-19 outbreak. Najwa Shihab is a former news anchor on Metro TV television station. She has served as an anchor on the news program Prime Time Metro Today, Your Voice and the talk program Mata Najwa. The recognition of Najwa's professionalism as a journalist came from within and outside the country. She has received several awards in the field of journalism. Those are awards from center PWI and PWI Jaya for the 2004 Aceh Tsunami report, on Best Journalist Metro TV (2006) nominated for the Best News Reader for the Panasonic Awards. She was being selected as a participant in the Senior Journalist Seminar (2005) which took place in a number of cities in the US, and she was a speaker at the Asian American Journalist Association Convention, nominated for the (top 5) Asian Television Awards (2007) in the category of Best Current Affairs / Talkshow Presenter. Until 2020, Najwa Shihab has been a journalist for 10 years. Karni Ilyas, has been a journalist since 1972. Until 2018, we have received 4 awards as a journalist, the Panasonik Gobel Award (2013), the Indonesian Broadcasting Commission Award (2015), the Panasonik Gobel Awards (2016), and the Panasonik Gobel Awards ( 2018). This shows that Najwa Shihab and Karni Ilyas are influential senior journalists in Indonesia.

The data source of this research is that journalists' speeches can be obtained from the YouTube page http://tiny.cc/abfysz and http://tiny.cc/0bfysz during April to May, the data used in this research is the speech of journalists who are suspected to contain humanist expressive speech acts.

The data collection technique used in this research is using the free-non participatory listening and recording techniques. In the freenon participatory listening technique, researchers downloaded videos of journalists who are well known to the public, Najwa Shihab and Karni Ilyas, via the YouTube page on the covid-19 outbreak during March to May. Furthermore, the technique used is the notetaking technique, the downloaded videos are converted into manuscripts, there are 9 manuscripts from the data that have been sorted. The data are then sorted and analyzed based on the form and function of the speech, then used as data cards.

This study used data validity by means of triangulation techniques of the data source. Triangulation is a data validity checking technique that utilizes something other than the data for checking purposes or as a comparison to the data (Moleong, 2015). Source triangulation is done by checking the data that has been obtained by listening to the video that has been downloaded. Theory triangulation is a variety of related theories to ensure that the data collected with the requirements.

The data analysis method used in this research is the equivalent method. The matching method used in this study was the pragmatic matching method, then continued with the basic technique, namely the Sorting Determining Elements (PUP/Pilah Unsur Penentu) technique to classify the form and function of a journalists' utterances.

\section{RESULTS AND DISCUSSION}

The results of research on expressive humanist speech acts of journalists during this outbreak found direct and indirect speech acts. Humanist expressive speech acts during the covid-19 outbreak, using direct and indirect forms of speech. Direct speech occurs when there is a conventional fit of speech mode and function. Indirect speech occurs when there is a 
mismatch between mode and function in speech. The mode of speech in two forms of expressive speech by humanist journalists during the covid19 outbreak can be seen in the following table.

Table 1.The Forms of Expressive Humanist Speech Acts of Journalists

\begin{tabular}{llll}
\hline No & Form & Mode & Frequency \\
\hline \multirow{3}{*}{1} & \multirow{3}{*}{ Direct } & Declarative & $52 \%$ \\
& & Interrogative & $3 \%$ \\
& & Imperative & $3 \%$ \\
& & Declarative- & $39 \%$ \\
2 & Indirect & Imperative & \\
& & Declarative- & $3 \%$ \\
& & Interrogative & \\
\hline
\end{tabular}

The results of the analysis on humanist journalist expressive speech acts on YouTube during the covid-19 pandemic, found that there were direct and indirect forms of speech acts. The form of direct speech acts used by journalists, $52 \%$ used the declarative mode, 3\% interrogative, and 3\% imperative. This shows the tendency of journalists use the declarative mode in the form of direct speech. The indirect speech acts used by journalists were 39\% in the declarative-imperative mode and $3 \%$ using the declarative-interrogative mode. This shows that journalists tend to use the declarative-imperative mode in indirect speech. The followings are the examples of the utterances.

\section{Direct Speech Acts \\ Declarative Mode}

Declarative mode is a mode that contains information that is used to provide information between interlocutors. This mode states the actions that will manifest through the one's willingness to influence the others' willingness. Several journalists' utterances that use the declarative mode are as follows.

(1) Context : The $1^{\text {st }}$ journalist speaks on the video entitled

Corona: Kepastian

diantara ketidakpastian..

In the video, $1^{\text {st }}$

Journalist shares her

feelings that she has

only been at home for 1

month due to the Covid-

19 outbreak. Najwa

conveyed that many people question how long this pandemic will end.

$1^{\text {st }}$

Journalist

But honestly, no one really knows when this outbreak will end. It is impossible for us to know without accurate data. (Tapi jujur, memang tidak ada yang tahu kapan pandemi ini aka $n$ berakhir. Mustahil kita bisa tahu tanpa data yang akurat). (data 76)

The utterances of data 76 are the utterances of the 1st Journalist in the video with the title Corona: Kepastian diantara ketidakpastian. The utterances are the humanist expressive speech acts. When there are many questions that asks about when this pandemic will end soon. Journalists conveyed their feelings that they also did not know when this pandemic would end. Journalists also conclude that it is impossible for the society, including journalists, to know when this pandemic will end without accurate data. The utterances have a convention between its mode and function, so that it can be classified into the form of direct speech acts. The mode used in the speech is declarative mode. The 1st Journalist uses the declarative mode to express feelings, saying that she does not know when this pandemic will end.

(2) Context : The anchor had a conversation with the $2^{\text {nd }}$ Journalist as the chief editor of one of the private TV stations in Indonesia. The topic of discussion was the impact of several regions that have implemented large-scale social restrictions, these restrictions certainly have an impact on the economy of the society. 


$\begin{array}{ll}\text { Anchor } \quad \text { Mr. Karni, what is your } \\ \text { opinion about social } \\ \text { assistance due to the effect } \\ \text { of Corona? (Pak Karni, } \\ \text { bagaimana pandangan } \\ \text { Bapak soal bantuan sosial, } \\ \text { efek dari corona ini?) } \\ 2^{\text {nd }} \text { Journalist } \quad \text { Yes, in my opinion, the } \\ & \text { absolute condition to make } \\ & \text { success for the PSBB is } \\ & \text { directly proportional to the } \\ & \text { smooth running of social } \\ & \text { assistance. } \\ & \text { (Ya kalau menurut Saya, } \\ & \text { syarat mutlak dari } \\ & \text { berhasilnya PSBB itu } \\ & \text { berbanding lurus dengan } \\ & \text { lancarnya bantuan sosial.) } \\ & \text { (data 178) }\end{array}$

The 178 utterances data are a part of the TV news anchor with $2^{\text {nd }}$ Journalist, as the chief editor of TV. The form of speech acts which were spoken by $2^{\text {nd }}$ Journalist when answering questions was in the form of direct speech acts. The speech has a match between the mode of speech and its conventional function. The mode used by Journalist 2 in the speech is the declarative mode. The information given by $2^{\text {nd }}$ Journalist to the public is his thought, if the PSBB is said to be successful, then social assistance should be distributed smoothly to the community. The humanist value contained in the speech, $2^{\text {nd }}$ Journalist does not force the public or interlocutor to have one opinion. $2^{\text {nd }}$ Journalist gives pressure when saying "I think", it shows that journalists are just conveying their thoughts.

\section{Interrogative Mode}

The interrogative mode is a mode that contains a question that is used to ask something to the interlocutor. This mode states actions that are not known to the speaker and hopes that the speech partner will provide an explanation of something.

(3) Context : Many questions from netizens ask when the

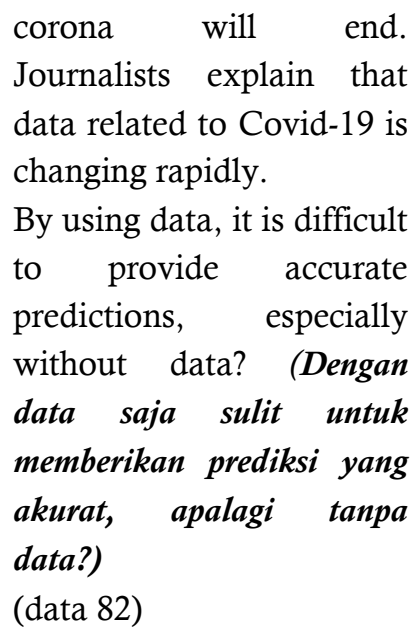

corona will end. Journalists explain that data related to Covid-19 is changing rapidly. predictions, especially without data? (Dengan data saja sulit untuk memberikan prediksi yang akurat, apalagi tanpa data?)

(data 82)

Najwa : By using data, it is difficult

Shihab to provide accurate

In the context of the 82 data, many questions from netizens ask when the corona will end. Through a video uploaded on the YouTube page, Najwa Shihab provides an explanation. In this speech, Najwa Shihab asked netizens how we could predict without data.

The expressive speech acts contained in the above conversation sections include direct speech acts because they have the appropriate speech mode and function. The function of interrogative speech is to ask questions, namely questions asked by journalists to citizens. The humanistic value contained in these utterances, netizens better understand the environment they are currently facing during the outbreak. Najwa Shihab did not immediately ask, but gave a brief description of the situation first, then asked questions. Najwa Shihab's speech felt polite and easier to be accepted by netizens.

\section{Imperative Mode}

Imperative mode is a mode that contains an order or request that is used to give orders or requests, emphasize willingness, and state prohibitions. The results of the analysis show that there are three journalists' utterances that use the imperative mode.

$\begin{aligned} \text { (4) Context : } & \text { There has been a } \\ & \text { phenomenon of society } \\ & \text { isolating people who are } \\ & \text { suspected of being positive } \\ & \text { for Covid - 19. Najwa } \\ & \text { Shihab gave a } \\ & \text { disappointment response }\end{aligned}$




$\begin{aligned} & \text { to the phenomenon that } \\ & \text { Najwa } \quad: \quad \text { Remember the old slang, } \\ & \text { Shihab } \text { stay away from the } \\ & \text { disease, not the person, } \\ & \text { this should be our grip!" } \\ & \text { ("Ingat jargon lama, jauhi } \\ & \text { penyakitnya bukan } \\ & \text { orangnya, seharusnya ini } \\ & \text { jadi pegangan kita!") } \\ & \text { (data 61) }\end{aligned}$

The utterances of 61 data occurred in a video fragment, when giving a response about the number of people who began to isolate Covid-19 sufferers. Journalists asked citizens to remember the old jargon, what should be avoided is the disease, not the sufferer. The journalist's speech is direct because the mode and function of the speech are interrelated. The speech takes the form of an imperative or an order, which instructs the netizen to remember the old jargon "stay away from the disease, not the person" as a guide in action. The humanist value contained in the speech reflects the concern of journalists for Covid-19 suspected. Journalists remind netizens do not isolate Covid19 suspected.

\section{Indirect Speech Acts}

\section{Declarative-Imperative Mode}

Declarative - imperative mode is a mode of speech acts that is declarative but intends to express the imperative meaning. In his speech, the speaker intends to give orders to his speech partner to do something, but the speech is expressed in a declarative mode is not appearing to be commanding.

$\begin{aligned} \text { (5) Context : } & \text { Najwa Shihab told of a } \\ & \text { phenomenon that is } \\ & \text { happening, many people } \\ & \text { are isolating Covid-19 } \\ & \text { suspected. }\end{aligned}$

Najwa : $P D P$ or $O D P$ patients are Shihab victims. Help them isolate themselves in their homes.

(Pasien PDP atau ODP adalah korban. Bantu mereka mengisolasi diri di rumahnya masing-masing.)

(data 49)

The statement on data 49 occurred when Najwa Shihab conveyed the feeling of her heartbreak that she was experiencing, seeing the phenomenon that was happening during the outbreak. Many people even inhumanely isolate Covid- 19 suspected. The utterance does not have an appropriate between the mode and function of the speech. In his speech, "ODP or ODP patients are victims. Help them isolate themselves in their homes", in the form of a declarative speech. When speaking the tone used by Najwa Shihab is a down tone, it can be identified as a declarative mode. The function of declarative speech is to provide information, but in this speech it functions to indirectly order citizens to help PDP or ODP patients to isolate themselves in their respective homes. The humanist value in this conversation piece (4) shows Najwa Shihab's concern for the community during the pandemic. This concern was proven by Najwa reminding the internet to help PDP and ODP patients isolate themselves in their respective homes. If the patient finds it difficult to self-isolate and leave the house, it will spread the virus to other communities.

\section{Declarative-Interrogative Mode}

Declarative - interrogative mode is a speech mode that is declarative but intends to express interrogative meanings. In his speech, the speaker intends to ask the other speaker questions, but the speech is expressed in a declarative mode.

(6) Context : Najwa Shihab gives the opening to the video. Njawa conveyed her feelings that have been at home for several months.

Jurnalis : Friends, we have passed for more than two months, maybe it feels longer than the usual 2 months.

(Teman-teman dua bulan lebih sudah kita lalui, mungkin lebih terasa panjang 


\section{dibanding 2 bulan biasanya.) (data 118)}

The statement on the 118 data occurred when Najwa Shihab opened the video with the title "Kenapa Tidak Sia-sia di Rumah Aja", in the video Najwa Shihab conveyed her feelings. The utterance does not have a correlation between the mode and function of the speech. The mode used in the speech is declarative mode. The function of declarative speech is to provide information, from this speech Najwa Shihab provided information that it has been 2 months since facing an outbreak, so you have to stay at home. In this utterance, Najwa Shihab emphasizes the word "maybe". This shows that Najwa Shihab intends to ask the netizen about this. Najwa Shihab explicitly asked netizens, "Do you feel the same way?" The humanist value in the conversation section (5) is Najwa Shihab's concern for the netizen. What netizens feel, Najwa Shihab also directly feels, so that the emphasis on the word "maybe" implies that Najwa Shihab also feels the same way.

\section{CONCLUSION}

Based on the results of this research obtains from nine video transcriptions found 103 humanist expressive speech acts. In the amount is $58 \%$ of the speech forms used by journalists during the pandemic were indirect speech and $42 \%$ used the form of direct speech. The mode of direct speech acts that was widely used by journalists during the Covid-19 outbreak was declarative. The imperative and interrogative utterances modes are not widely used by journalists; the frequency is that there are only 3 utterances using the imperative mode and 3 utterances using the interrogative mode. The form of indirect speech acts used by journalists during the Covid-19 outbreak used the declarative-imperative mode and the declarativeinterrogative mode. Journalists tend to use more declarative-imperative speech with a frequency of 40 utterances. In his speech, the journalist intends to give orders to the speech partner to do something, but the speech is expressed in a declarative mode so that it does not appear to be commanding. This is appropriate with Taylor's theory (Agung, 2020: 70), that a pandemic has a broad and massive psychological impact on society. People experience changes in ways of thinking and emotional changes in understanding information in society. Journalists as a door to disseminate information need to be careful so as not to cause social conflict. The form of direct humanist expressive speech acts with the declarative mode is an alternative that can be used by journalists in conveying information, so that there are no misunderstandings.

The suggestions that can be recommended are as follows: (a) journalists in conveying information during an outbreak, it is important to create speeches that can motivate and educate speech partners without offending speech partners. (b) the use of humanist expressive speech acts is expected to be cultivated in various interactions, not limited to journalist interactions on YouTube. (c) other researchers are expected to develop similar research by expanding the object of study, including expressive speech acts of humanists, medical personnel, regional heads, parents, and so on during the covid-19 pandemic.

\section{DAFTAR PUSTAKA}

Agung, I. M. (2020). Memahami Pandemi Covid19 dalam Perspektif Psikologi Sosial. Psikobuletin: Buletin Ilmiah Psikologi, 1(2), 68-84. http://ejournal.uinsuska.ac.id /index. php/Psikobuletin/article/view/9616/505 8

Ariyanti, L. D., \& Zulaeha, I. (2017). Tindak Tutur Ekspresif Humanis dalam Interaksi Pembelajaran di SMA Negeri 1 Batang: Analisis Wacana Kelas. Seloka: Jurnal Pendidikan Bahasa Dan Sastra Indonesia, 6(2), 111-122.

Bavel, J. J. V., Baicker, K., Boggio, P. S., Capraro, V., Cichocka, A., Cikara, M., Crockett, M. J., Crum, A. J., Douglas, K. M., Druckman, J. N., Drury, J., Dube, 
O., Ellemers, N., Finkel, E. J., Fowler, J. H., Gelfand, M., Han, S., Haslam, S. A., Jetten, J., ... Willer, R. (2020). Using Social and Behavioural Science to Support Covid-19 Pandemic Response. Nature Human Behaviour, 4(5), 460-471. https://doi.org/10.1038/s41562-0200884-z

Chaer, A., \& Agustina, L. (2004). Sosiolinguistik Perkenalan Awal. Jakarta: Rineka Cipta.

Ekawati, M. (2017). Kesantunan Semu pada Tindak Tutur Ekspresif Marah dalam Bahasa Indonesia. Adabiyyat: Jurnal Bahasa Dan Sastra, I(1), 1-22.

Eliya, I., \& Zulaeha, I. (2017). Pola Komunikasi Politik Ganjar Pranowo dalam Perspektif Sosiolinguistik di Media Sosial Instagram. Seloka: Jurnal Pendidikan Bahasa Dan Sastra Indonesia, 6(3), 286-296. http://journal.unnes.ac.id/sju/index.php /seloka

Giatman, M., Siswati, S., \& Basri, I. Y. (2020). Online Learning Quality Control in The Pandemic Covid-19 Era in Indonesia. Journal of Nonformal Education, 6(2), 168-175. https://doi.org/10.15294/jne.v6i2.25594

Hardika, H., Aisyah, E. Nu., \& Kurniawan, T. (2020). Literacy About Covid-19: Trending Words, News Sources, Compre-hension, and Community Curiosity in Perspectives Nonformal Edu- cation. Journal of Nonformal Education and Community Empowerment, 6(2), 161-167.

How, C., \& Jan, J. M. (2019). Speech Act of Concern on The Academic Performance of Malaysian Foster Children. GEMA Online Journal of Language Studies, 19 (3), 88108. https://doi.org/10.17576/gema2019-1903-06

Indrayanti, N., Haryadi, H., \& Baehaqie, I. (2019). Tindak Tutur Ilokusi dalam Wacana Naskah Drama Deleilah Tak Ingin Pulang dari Pesta Karya Puthut E.a. Jurnal Sastra Indonesia, $\quad 8(1), \quad 62-67$. https://doi.org/10.15294 /jsi. v8i1.29951
Kurniawan, N. A., Saputra, R., Daulay, A. A. (2020). Implementasi Prinsip-Prinsip Merdeka Belajar Bagi Calon Konselor. Prosiding Seminar. http://conference. um.ac.id/index.php/bk/article/view/60

Mitchell, P. (2014). The Ethics of Specch and Thought Representation in Literary Journalism. Journalism, 15(5), 533-547.

Moleong, L. J. (2015). Metode Penelitian Kualitatif. Bandung: Remaja Rosda Karya.

Rini, S., \& Wagiran. (2018). Humanist Expressive Utterance Function and Form in Teaching Learning Interaction at Vocational High School. Seloka: Jurnal Pendidikan Bahasa Dan Sastra Indonesia, 7(2), 244-250.

Ristyawati, A. (2020). Efektifitas Kebijakan Pembatasan Sosial Berskala Besar dalam Masa Pandemi Corona Virus 2019 oleh Pemerintah Sesuai Amanat UUD NRI Tahun 1945. Administrative Law \& Governance Journal, 3(2), 240-249. https://doi.org/ 10.14710/ALJ.V3I2.240-249

Rustono. (1999). Pokok-Pokok Pragmatik. Semarang: CV IKIP Semarang Press.

Wijana, I. D. P. (1996). Dasar-Dasar Pragmatik. Yogyakarta: Andi Offset.

Wilkins, L. (2005). Plagues, Pestilence and Pathogens: The Ethical Implications of News Reporting of a World Health Crisis. Asian Journal of Communication, 15(3), 247254.

https://doi.org/10.1080/0129298050026 0698

Xiong, J., Lipsitz, O., Nasri, F., Lui, L. M. W., Gill, H., Phan, L., Chen-Li, D., Iacobucci, M., Ho, R., Majeed, A., \& McIntyre, R. S. (2020). Impact of Covid-19 Pandemic on Mental Health in The General Population: A Systematic Review. Journal of Affective Disorders, 277(July), 55-64. https://doi.org/10.1016/j.jad.2020.08.00 1 